\title{
14
}

\section{Governing the Community-Based Natural Resource Management System in Northern Australia: Challenges and Opportunities}

\author{
Allan P. Dale, Gabriel Crowley, Tom D. Brewer, Kate
} Andrews, Brian Warren, Karen Vella and Ruth Potts

\section{Introduction: Australia's Community- Based Natural Resource Management System}

Australia's community-based NRM (CBNRM) system is underpinned by cohesive policy, program and delivery arrangements. It uses suasive, non-regulatory approaches to achieve outcomes at the landscape scale. Dale et al. (2017) and Curtis et al. (2014) reviewed the origins and health of the nation's CBNRM system. They find that while these systems originated via state government efforts in soil conservation and catchment management, Commonwealth efforts began with the National Soil Conservation Program (1983-92), evolving into the National Landcare Program (NLP, 1993-present), the Natural Heritage Trust (NHT1, 1997-2001 and NHT2, 2001-08), the National Action Plan for Salinity and Water Quality (NAP, 2001-08) and the Caring for our Country (CfoC) Program and associated funds (2008-13). CfoC later transformed into the NLP (Dale et al., 2017). 
The establishment of a national framework for regional NRM under NHT2 in the early 2000s was a major step change for Australian CBNRM and saw the establishment of 56 regional NRM bodies-a move informed by the National NRM Policy Statement Steering Committee's (1999) report. A significant consequent improvement in the national CBNRM system was the tying together of agricultural and environment goals through this framework. The mechanisms have changed through time but a constant approach has been the contribution of funds from both Commonwealth agriculture and environment portfolios and the involvement of both ministers and the states/territories. This rare and difficult cooperation across governments and government agencies and policy silos has been pivotal to achieving landscape-scale management.

While the CBNRM system originally emerged from both statutory and Landcare models in the southern states, it was later, in part, appropriated by Commonwealth agencies. With increasing Commonwealth influence, a bilaterally agreed policy framework for CBNRM was negotiated with state and territory governments which, except for the Northern Territory (NT), all have capitals south of the Tropic of Capricorn. Consequently, the basic form and function of governance and design of the CBNRM system and its evolution paid little attention to the challenges facing communities and landscapes in Australia's remote north.

From 2001, regional NRM bodies were established to develop and maintain regional NRM plans to guide management action (Paton et al., 2004)—planning that aimed to secure regional consensus on aspirational and (nationally-guided) resource condition targets. NRM bodies also developed investment and engagement strategies to motivate land managers to improve management practices. Programs and projects given auspice under these arrangements were delivered by partner organisations such as Landcare groups, Traditional Owners, industry bodies, environment groups, councils or consultants (Dale et al., 2017). Despite the centralisation and move away from government bilateral agreements from 2007 onwards, the governance system retained some of these core features. Hence, a difference in the north has been that, while some southern jurisdictions (e.g. Victoria and New South Wales) delivered bilateral NRM via pre-existing statutory-based catchment management institutions (Ryan et al., 2010), the three governments across Northern Australia established non-government delivery organisations. With 
the decline of bilateralism between the Commonwealth and the states/ territories, this has limited the institutional capacity of NRM bodies through limited government commitment and resourcing for long-term planning and implementation within the regional NRM framework.

Additionally, NRM planning in Northern Australia has also been impeded by a lack of environmental inventories, maps, monitoring systems, asset identification or knowledge of ecosystem function, so it was disproportionately affected by the disbanding of the National Land and Water Resources Audit in 2008 and Land and Water Australia in 2009. NRM planning in northern and remote areas had generally used tailored approaches (such as expert elicitation) to progress action in the face of data deficiencies while also prioritising investment in improving the research and knowledge base (Dale, Pressey et al., 2014). However, as northern assets remained under-represented in national databases, northern NRM was once again disadvantaged when CfoC shifted investment prioritisation from regional NRM plans to identified national assets and reduced support to research and knowledge building activities at the cross-regional and regional scales.

While the national emergence and refinement of the regional NRM framework was a governance innovation from the early 2000s, regional NRM governance capacity was uneven geographically and between sectors (Hill et al., 2013; Ryan et al., 2010). This was an issue in the north, where reduced institutional capacities slowed the engagement of Indigenous, industry and conservation interests. Similarly, blunt bilateral negotiations saw some parts of the national landscape under-resourced for implementation efforts (e.g. Central Australia). On the whole, however, all landholders in most regions across Australia, for the first time, were able to elect to become part of a predictable NRM process via extension, training and incentive-based activities (Dale et al., 2017). Collaborative projects were encouraged and stable resourcing had become available to implement priority actions. 


\section{Systemic Governance Challenges in the North}

With this policy and program-focused history in mind, this chapter first considers those contextual differences in Northern Australia that pose challenges for the successful design and delivery of nationally oriented and state/territory-based CBNRM policies and programs.

\section{Northern Australia is an Indigenous Domain}

Dale (2013) considered Northern Australia culturally very different to the south of Australia and one of the world's most expansive Indigenous domains. He suggested that as Aboriginal and Torres Strait Islander people have control of, and/or interests in, the vast majority of the landscape, from a human rights perspective, Australia will continue to face pressure to engage seriously in Indigenous aspects of natural resource use to close the socioeconomic gap between Indigenous and non-Indigenous Australians. Statutory land and native title rights must also continue to be resolved across the wider landscape, while native title remains an evolving area of case law (JCU \& CSIRO, 2013). The challenge this creates is that NRM policies/programs designed in Southern Australia, generally, are not well placed to meet the aspirational and practical needs of Traditional Owners (Dale, 2014).

\section{Climatic Differences and Limited Operational Windows}

Climatically, the windows available for implementing CBNRM activities in Northern Australia are seasonally constrained in a major way. Accessibility is severely hampered during the wet season when the north's limited road networks are frequently impassable. Deep dry seasons bring altogether different challenges associated with fire management and water stress. Cyclones and severe flooding are a real possibility each wet season (Bureau of Meteorology, 2015). Consequently, project/budgetary cycles designed for more benign southern climates do not match northern conditions in practical ways. These constraints must be taken into account when reviewing NRM program progress against expectations. 


\section{Institutional and Human Resource Capacities}

Anyone trying to run an institution in Northern Australia understands the implications of limited human resource capability. This is relevant for the strategic development, implementation and monitoring of programs and projects. Workers in not-for-profit institutions face a higher cost of living in the north and, by and large, are paid less than their southern counterparts. High-paying industrial and public service sectors compete for available skills, leading to booms and busts in skilled workforces. Both local and migration-based workforces can also be both younger and more transient, a consequence of lower levels of liveability and isolation (Dale, 2013). Remoteness can lead to transience and higher cost in doing business (Martell et al., 2013), with implications for the capacity of both strategic and delivery-oriented NRM institutions.

\section{A Focus on Landscape Protection versus Restoration}

National NRM programs continue to focus on tree planting and other rehabilitative activities to restore ecological function in largely agricultural landscapes. As the north retains most of its tree cover (an artefact of the vast expanses of economically marginal country), it is perceived to be in better condition than southern landscapes. Serious environmental degradation, however, has progressed under the tree canopy higher grazing pressures, disruption of fire management, and weeds and feral animals contributing to the most serious species losses to occur in the last half-century (Doody et al., 2009; Franklin, 1999; Russell-Smith et al., 2003; Woinarski et al., 2007; Woinarski et al., 2015; Woinarski et al., 2007). CBNRM initiatives, therefore, should focus on the identifying causes of ecosystem dysfunction and measures to address them. Durable and stable on-country programs are essential to restore the nexus between people and the environment and to maintain knowledge of ecosystem function via fire, weed and feral animal management (Woinarski et al., 2014).

There are many examples where this is working well, notably the Western Arnhem Land Fire Abatement (WALFA) project (Whitehead et al., 2009) and emerging community-based pollution reduction programs in the Great Barrier Reef (Brodie \& Waterhouse, 2012). Like much of the rest of the nation, however, such projects can only be effective if 
there is a more widespread change from the current project-based and short-term funding model. They need to be underpinned by community support, on-ground (often traditional) knowledge and robust science, including extensive use of satellite imagery and modelling. They also need governance frameworks designed to ensure gradual incorporation of ecosystem service delivery into a marketable commodity. WALFA, for example, has transitioned from an on-country fire management project to a major savanna-burning program supporting some 33 carbon abatement projects over $140,000 \mathrm{~km}^{2}$. This foundation promises to support land management at levels never before seen in the north. Similar approaches of scaling up from local to cross-regional activities that can be converted to marketable commodities would ensure the delivery of enduring landscape outcomes. Such initiatives, however, are hampered through policy and price uncertainty in Australia's carbon market and a general lack of ecosystem service policy (Dale et al., 2014).

\section{Conflicts Between Resource Exploitation and Preservation}

One of the more difficult challenges facing NRM governance in the north is balancing economic development through resource exploitation with landscape preservation (Stephens et al., 2015). The historical introduction of improved pasture plants later classified as weeds and environmental and industry competition over water allocation are two examples. Often the poor management of conflict between these competing agendas leads to failed development and failed environment policy and investment (Stephens et al., 2015). These problems are exacerbated by a dearth of adaptive approaches to land use planning across Northern Australian landscapes. However, the emergence of new ecosystem service markets, including carbon farming, solar radiation capture, Indigenous land and sea knowledge and innovative nature tourism opportunities, could reduce conflict. They can provide additional income streams to complement more traditional forms of development (Dale, 2014). Their growth, however, requires NRM governance arrangements to build private and public partnerships that improve access to funding and shares costs across multiple sectors. 


\section{The Northern Progression of Community- Based Natural Resource Management}

Having built the above understanding of major challenges facing the progression of CBNRM in Northern Australia, the following explores specific aspects of historical development of the concept across the three key jurisdictions (Queensland, NT and Western Australia [WA]). This allows us to draw out key conclusions for the growth and development of appropriate CBNRM governance systems in the north.

\section{Progression of the System in Northern Queensland}

The early 2000s saw a progressive maturation of regional CBNRM programs in Queensland. This provided an enhanced institutional capacity for NRM in the north. The Queensland Government opted for a community-based form of regionalism and continuous improvement through cooperative bilateralism, the accreditation of evidence-based and engaged regional NRM plans and the designation of regional NRM body capacity. Between 2001 and 2007, this policy phase ushered in a growth in more integrated NRM (INRM) efforts in the north, including the establishment of 12 designated regional NRM bodies. These emerging institutions were, however, weakened with the more centralised program delivery approach ushered in under CfoC in 2007. CfoC's introduction heralded great financial uncertainty for regional bodies and delivery partners, a problem only partially resolved by the Australian Government eventually committing some 60 per cent of stable pre-2007 investment as guaranteed funding via regional NRM bodies and their delivery partners (Dale et al., 2017).

By 2013, the swing in Commonwealth support away from integrated regionalism had reduced institutional stability in northern regions and increased policy/financial uncertainty as well (Dale et al., 2017). In the Wet Tropics, for example, while the region's NRM body fared well under the CfoC program (e.g. via Reef Rescue funding), from 2007, there was a parallel short-term collapse in the capacity of the regional body to support biodiversity, pest management and Indigenous land and sea management. Importantly though, the Wet Tropics region's capacity to secure Reef Rescue and Indigenous Protected Area (IPA) funds was, in part, a legacy from the stable institutional arrangements operating pre-CfoC. 
The Australian Government's shift away from bilateralism also left North Queensland regions more vulnerable to shifting policy environments within the state government. Also, using the Wet Tropics as an example, the introduction of $\mathrm{CfoC}$ stalled progressive improvements in the development of cohesive delivery systems in local government, the conservation sector and in the Landcare and catchment management sectors. Conversely, by exception, time-bound programmatic funding (with a specific investment horizon) via CfoC's Reef Rescue Program, for example, improved capability in the agricultural sector while IPAs funded capacity advances in the Indigenous sector (Dale et al., 2017).

\section{Progression of the System in the Northern Territory}

Formalised INRM in the NT began in 2003 with the signing of the bilateral agreement for NHT delivery between the NT Government and the Commonwealth (Commonwealth of Australia \& Northern Territory, 2003). The Landcare Council of the NT (LCNT) was recognised as the regional delivery body (LCNT, 2005). LCNT had been established in 1990 as the peak community and industry body advising the NT Government on NRM matters. All 14 council members were NT Government appointees and included diverse participants. The NT was alone with the Australian Capital Territory in having one body covering the whole jurisdiction. LCNT was tasked with developing the first NT INRM Plan (LCNT, 2005). On completion of this plan, LCNT was replaced by the NRM Board of the NT (NRMBNT), later called Territory NRM. Changes to the governance of Territory NRM since 2012 have included updating the constitution to replace responsibility for board appointments from the NT Government to a community member-based panel. The INRM Plan was revised in 2010 (Territory NRM, 2010) and is currently undergoing a second revision.

From 2005, NRMBNT operated as a priority-setting and funding body. It administered competitive funding for projects delivering on INRM Plan priorities. It supported NRM activities of community, industry and government aligned to the plan. With the transition to CfoC in 2007, Commonwealth funding that would previously have supported this process was delivered through open funding rounds to meet the newly devised Commonwealth priorities, rather than regional plans. This restricted the capacity of NRMBNT to implement the plan and the role of NRMBNT in supporting NRM activities. Following the demise of 
NRM-based bilateral agreements, Commonwealth grants to the regional body fell from over $\mathrm{A} \$ 8$ million in $2007 / 08$ to about $\mathrm{A} \$ 6.4$ million in 2009/10 and A \$5.2 million in 2013/14, with no cash contributions to from NT Government (Department of Natural Resources, Environment, The Arts and Sport, 2011; Territory NRM 2014). Despite the reduced funding, improved program security was maintained through five-year base-level funding for regional bodies through CfoC from 2011 and in the NLP.

Commonwealth budget allocations to the NT have always been disproportionately small. The NT constitutes some 17.5 per cent of Australia's land area and 17.5 per cent of its marine area, but typically receives less than 5 per cent of Commonwealth environmental management funds. Indeed, NHT funding from 1996-2000 fell to 3.1 per cent of the national total (Williams et al., 2001). Inadequate funding was exacerbated in the national open-call process, as NRM organisations in the NT were uncompetitive under the $\mathrm{CfoC}$ priorities of: 1) rehabilitation of degraded landscapes, 2) the management of a priority asset lists, or 3) increased participation rates. Substantial Commonwealth support for the operation of the Northern Australian Indigenous Land Management Alliance (NAILSMA) projects were a notable exception.

The destabilising result of decoupling Commonwealth funding from the NT INRM plan was illustrated by the outcome of the CfoC 2009-10 Business Plan, in which one of two projects funded in the NT were for control of rats on Truant Island. While the control of rats on islands was a Commonwealth priority (Department of the Environment, Water, Heritage and the Arts, 2009) and eradication from Truant Island was specifically mentioned in the CfoC Business Plan (Australian Government Land and Coasts, 2008), neither Traditional Owners nor conservation ecologists contributing to the 2010 NT NRM Plan identified either as a priority. The project eventually foundered because of lack of support from the Traditional Owners and funding was withdrawn.

The NT, thus, presents a unique case. Its regional body covers the entire Territory and its plan reflects priorities of the community, industry and government. Increasing integrated regionalism to underpin of delivery of Commonwealth funding through the regional body should, therefore, deliver on Territory priorities, but would also ensure that the science behind the funding allocation is well suited to the region and that high levels of community ownership of projects would deliver high success rates. 


\section{Progression of the System in Northern Western Australia}

The northern area of WA is large with a low population density. The 2011 Census shows the Kimberley has a total population of about 34,794 with over half of these people in the major towns. The remaining 16,500 are in smaller centres and/or engaged in pastoralism across an area of about 42.1 million hectares. About 40 per cent of the population are Indigenous. Establishment and development of regional NRM programs in WA has similar characteristics to the Queensland model. This is true even to the extent that the 2007 Commonwealth pullback from NRM support made the WA regional NRM groups and communities vulnerable to the changed state government policy environment, even though direct state government funding to NRM in WA had been low since the demise of NHT-NAP in 2007. The Commonwealth-WA Government bilateral agreement during NHT supplied matching funding that was almost always delivered through in-kind by the state. This was important for providing skills and technical resources to northern NRM activities and these are now much reduced.

As in Queensland and the NT, the NHT-NAP period was progressive for regionally based NRM. In northern WA, there was a unique situation where very disparate communities, spread across large areas, needed to be engaged to deliver a broad suite of NRM programs, often for the first time. This difficulty was recognised at the time of establishment of the NHT programs in the early 2000s and the regional NRM group (Rangelands NRM WA) undertook a planning process to engage communities and to develop a genuine community basis for the NHT-NAP programs. Rangelands NRM WA consulted with communities and individuals across the north to identify the natural resources in their areas and to secure regional consensus on aspirational and resource condition targets and possible management options. This process was undertaken over a period of more than 12 months and led to a Rangelands NRM Investment Plan (Rangelands NRM Coordinating Group, 2005) to guide investment and engagement through NHT and NAP. This was the first time such an intense and detailed community consultation process had been carried out across the WA rangelands and communities, and individuals had good ownership of the investment plan and were supportive of the NHT-NAP programs (via the plans and community committees were established). Such support across communities in WA's north is unique and eventually paved the way 
for over 100 projects addressing many of the NRM issues identified in the consultation process. Several special interest environmental groups were also established to deliver programs and some continue to operate in the region (B. Warren, personal communication, 3 April 2015). This background highlights the importance of and opportunities for engaging people and retaining their participation to achieve social, economic or environmental benefits.

The more recent development of CfoC post-2007 and the more prescriptive formulas endorsed reduced community ownership. Projects that met CfoC criteria did not always align or support communityidentified NRM issues. As a result, many communities and groups became disillusioned and negative to the regional group and to the Commonwealth's programs, and several local groups have since failed due to capacity problems. The limited number of CfoC-identified natural assets in a region made it difficult to re-establish previous relationships and community ownership as achieved under NHT-NAP. The individual relationships with both Indigenous and non-Indigenous land managers across the north was also weakened, although the Sustainable Agriculture stream of $\mathrm{CfoC}$ provided an alternative, albeit relatively poorly funded, mechanism for engagement of pastoral land managers.

Most of the programs supported under CfoC did not take account of rangeland systems and frequently, in northern WA, support was only available to address issues of degradation and not protection of highquality assets. Although work on feral animal and weed control was vital, it did not engage well with many land managers. Control work generally had to be undertaken by trained professionals and was not 'suasive and community-based'. The loss of commitment to CBNRM by the land managers of the north became a critical issue. There was no genuinely demonstrated understanding by government that the people living and managing the land must be involved and own the actions required for positive and sustainable NRM outcomes (B. Warren, personal communication, 3 April 2015).

As previously stated, the prescriptive system developed for the agricultural areas of Southern Australia does not fit the needs of the north and will fail unless a new, community-focused approach that recognises the knowledge and commitment to country of the northern land managers is adopted. To deliver good NRM management outcomes across the remote north, it is absolutely essential that all land managers are engaged and committed 
to sustainable NRM. The vast areas that need management cannot be maintained without the land managers in place providing the services needed to sustain asset quality and slow degradation. It is clear that one size does not fit all in the NRM space and that a move to a different paradigm, where recognition of the importance of local communities is again understood, is essential to protect our Northern Australia assets.

\section{Some Common Learnings for Northern Australia}

\section{Cohesive Scale-Based Planning and Effort Mobilisation}

Northern Australian regional NRM bodies and communities generally experienced the $\mathrm{CfoC}$ era as a shift from an outcome-focused policy agenda, which aimed to mobilise bilateral and regional NRM effort, to a centralised and narrowly focused national grants program. These centralised changes responded to the 2008 Australian National Audit Office (2008) report on the regional delivery model that criticised a lack of reporting on investment outcomes. This put further pressure on constrained institutional and human resources. In respect to the Wet Tropics, Dale et al. (2017) reported:

- less alignment between state and Commonwealth policy efforts and diminished alignment of local government, industry and community investment against agreed targets

- declining collaborative effort among many major regional institutions (including state and local governments, regional NRM bodies, statutory authorities and research institutions)

- with some sectoral exceptions (e.g. parties funded under IPA, Working on Country [WoC, now Indigenous Ranger Programs] and Reef Rescue), increased competition with consequent transaction costs facing all parties

- declining planning and delivery capability among NRM stakeholders, but increased capacity in the Indigenous domain and investment in the national reserve system (see Hill et al., 2013). 
A retreat from target-driven bilateralism and coordinated regionalism, while intended to reduce transaction costs for the Australian Government, to a large extent simply increased the overall transaction costs in northern regions. Stakeholders now had to spend significant resources developing project proposals that were not necessarily compatible with regional priorities and achieved low success rates.

\section{Collaborative Frameworks for Research and Knowledge Management}

Without collaborative regional research frameworks, including knowledge exchange, investment in northern NRM research and development is driven by researchers or funding agencies. This limits the regional relevance and impact of research and its benefit to strategic long-term decision-making. Since 2010, the Australian Government has tended to centralise control and management of significant regional NRM research programs (Expert Working Group on Science Engagement into and for Australia's Tropical Region, 2012). This has increased transaction costs for regional communities in the north, and regional NRM bodies became less able to influence the development and monitoring of their internal programs with well-engaged science management arrangements. This additionally reduced the capacity of their regional communities to influence policy and investment decisions affecting regional NRM (Dale et al., 2017). Over the last decade, new consultation arrangements have been revitalised through the establishment of cluster-based research partnerships through Clean Energy Fund (CEF) funds from 2013 (e.g. see Hilbert et al., 2014), the new evolving National Environmental Sciences Program (NESP) hubs and the new Collaborative Research Centre for Northern Australia (CRCNA). These new approaches could help rebuild previous arrangements such as the older Tropical Savanna, Reef and Rainforest Collaborative Research Centre, Tropical Rivers and Coastal Knowledge (TRaCK) approaches. The new Collaborative Research Centre for Northern Australia (CRCNA) is also now strongly playing in the space, integrating efforts across the NESP hubs and southern research and development corporations (RDCs). 


\section{Environmental Accounts, Reporting and Adaptive Management}

Regional stakeholders require evidence about the condition and trend of natural resources to devise solutions and to know whether current practices, policies and investments are working and to help engage and mobilise the region's key land managers. Since 2007, however, there has been a shift away from building a nationally integrated resource condition monitoring framework that could provide national-scale baseline data on natural resource conditions. National monitoring frameworks for key assets have been progressing (e.g. water and vegetation) but this has tended to occur via centralised and fragmented effort based on key asset classes, weakening the capacity of northern regions to influence state and national policy and investment agenda. Additionally, a less focused national framework has diverted coordinative effort in the states and the NT with regard to holistic resource condition and trend monitoring. Some years ago, in recognition of these issues, collaborative, pilot-based work on monitoring and reporting regional natural resource condition and trend within a national accounting context was progressing in partnership between northern regional NRM bodies and the Wentworth Group (2008). This could inform positive new thinking and development in this area.

\section{Devolved Regionalism: Shared Common Success Factors}

While the broader $\mathrm{CfoC}$ framework eschewed devolved, multiscale approaches as a core tenet, some $\mathrm{CfoC}$ subprograms did use less centralised methods. The IPA subprogram, for example, provided devolved funds to Traditional Owner groups to plan the declaration and management of new IPAs. This funding was followed up with long-term delivery contracts through the WoC subprogram. These subprograms were also managed by a dedicated team of centrally based Indigenous NRM specialists and given operational flexibility. Consequently, Indigenous groups across Northern Australia made real gains in capacity and delivery. Similarly, the Reef Rescue subprogram, arguably CfoC's most high-profile success, was also negotiated by regional NRM, industry and conservation bodies ahead of the main CfoC framework (Dale et al., 2020). Governance innovations established under the NAP-NHT, however, had helped drive the evolution of these subprograms. 


\section{Landscape Based Carbon: An Emerging Opportunity}

Northern Australia has significantly influenced national thinking about using ecosystem service markets to deliver CBNRM outcomes. The initiation and operation of WALFA was supported with direct Commonwealth funding and the NRMBNT at times provided stop-gap funding for on-ground fire management, methodology development and the guiding of land managers through the Carbon Farming Initiative (CFI) accreditation process. While these developments emerged from a strong Indigenous agency, particularly through the NAILSMA, such groups were able to cast their work into policy frameworks that were also substantially influenced by other regional NRM bodies, particularly in Queensland (Dale, 2014). Hence, Australian Government reforms (from 2013 and earlier) under the CEF framework established the foundations for new ecosystem service markets/products of international standing in the north.

Attracting and guiding these emerging markets was a key goal underpinning the updating of regional NRM plans in the Monsoon, Arid Lands, Wet Tropics and South Eastern Queensland Clusters (Dale, Vella et al., 2014). By supporting the agricultural and land use sectors to trade in greenhouse gas abatement and other complementary ecosystem services (like biodiversity), these markets could transform NRM in Northern Australia. Enabling mitigation and abatement activities to become ecosystem service commodities would also allow northern regions to gain relative economic advantage from climate change rather than letting vulnerable regions be overwhelmed by it (Van Oosterzee et al., 2013). The Australian Government's new Emission Reduction Fund retains most of the key opportunities established under the CEF, ensuring real prospects for solid landscape outcome across the north.

\section{Conclusions}

While reforming the wider CBNRM governance system is nationally important in its own right, the system has specific weaknesses when considered in the Northern Australian context. Program short-termism and poor links between science and decision-making are key problems. More problematic, however, is the gap between a centralised policy agenda and the way it fails to address the needs of Traditional Owners 
and the pastoral and farming sectors in managing extensive estates across the north. Many of these needs relate to building long-term capacity of pastoralists and Indigenous land and sea institutions for NRM. This chapter argues that any reform of the national NRM governance system must pay attention to the needs of Northern Australia. The new and emerging discussions associated with implementation of the Commonwealth's Northern Australia white paper, ongoing refinement of the nation's CBNRM system and the emerging new NESP hubs and the new CRCNA present some opportunities to commence a pan-northern dialogue on these issues.

\section{Acknowledgements}

This work was funded by the Department of Industry, Innovation, Science, Research and Tertiary Education via the Northern Futures Collaborative Research Network, the Australian Government's Stream 2 Climate Adaptation Program, and the Australian Research Council. We would also like to thank the wide range of practitioners and experts involved in the Northern Australian CBNRM system for contributing their knowledge and experience to the chapter.

\section{References}

Australian Government Land and Coasts. (2008). Caring for our country business plan 2009-2010. Canberra, ACT: Department of Sustainability, Environment, Water, Population and Communities and Department of Agriculture, Fisheries and Forestry.

Australian National Audit Office. (2008). Regional delivery model for the National Heritage Trust and the National Action Plan for Salinity and Water Quality (Report No. 21). Canberra, ACT: Australian National Audit Office.

Brodie, J. \& Waterhouse, J. (2012). A critical review of environmental management of the 'not so Great' Barrier Reef. Estuarine, Coastal and Shelf Science, 104-105, 1-22. doi.org/10.1016/j.ecss.2012.03.012

Bureau of Meteorology. (2015). Australian weather and season: A variety of climates. Retrieved from www.australia.gov.au/about-australia/australian-story/austnweather-and-the-seasons (site discontinued) 
Commonwealth of Australia \& Northern Territory. (2003). Bilateral agreement between the Commonwealth of Australia and the Northern Territory of Australia to deliver the Natural Heritage Trust. Canberra, ACT: Australian Government.

Curtis, A., Ross, H., Marshall, G. R., Baldwin, C., Cavaye, J., Freeman, C., ... Syme, G. J. (2014). The great experiment with devolved NRM governance: Lessons from community engagement in Australia and New Zealand since the 1980s. Australasian Journal of Environmental Management, 21(2), 175-199. doi.org/10.1080/14486563.2014.935747

Dale, A. P. (2013). Governance challenges for Northern Australia (The future of Northern Australia Discussion Paper Series). Cairns, Qld: The Cairns Institute. Retrieved from researchonline.jcu.edu.au/29868/2/29868_Dale_ 2013.pdf

Dale, A. P. (2014). Beyond the north-south culture wars: Reconciling northern Australia's past with its future. London: Springer.

Dale, A. P., Pressey, R., Adams, V. M., Álvarez- Romero, J. G., Digby, M., Dobbs, R., ... Gobius, N. (2014). Catchment-scale governance in northern Australia: A preliminary evaluation. Journal of Economic and Social Policy, 16(1), Article 2.

Dale, A., Ryan, S. \& Broderick, K. (2017). Natural resources management as a form of multi-level governance: The impact of reform in Queensland and Tasmania. In K. A. Daniell \& A. Kay (Eds), Multi-level governance: Theory and case studies (pp. 327-359). Canberra: ANU Press. doi.org/10.22459/MG.11.2017

Dale, A. P., Vella, K. \& McKee, J. (2014). Analysing governance of Australia's system of landscape-based greenhouse gas abatement. Australasian Journal of Environmental Management, 21(4), 378-395. doi.org/10.1080/14486563. 2014.954644

Dale, A. P., Vella, K., Ryan, S., Broderick, K., Hill, R., Potts, R., ... Brewer, T. (2020). Governing community-based natural resource management in Australia: International implications. Land, 9(7), 234. doi.org/10.3390/ land 9070234

Department of the Environment, Water, Heritage and the Arts. (2009). Threat abatement plan to reduce the impacts of exotic rodents on biodiversity on Australian offshore islands of less than 100000 hectares. Canberra, ACT: DEWHA.

Department of Natural Resources, Environment, The Arts and Sport. (2011). Annual report 2010-11. Darwin, NT: Department of Natural Resources, Environment, The Arts and Sport. 
Doody, J. S., Green, B., Rhind, D., Castellano, C. M., Sims, R. \& Robinson, T. (2009). Population-level declines in Australian predators caused by an invasive species. Animal Conservation, 12(1), 46-53. doi.org/10.1111/j.1469-1795. 2008.00219.x

Expert Working Group on Science Engagement into and for Australia's Tropical Region. (2012). Science engagement and tropical Australia: Building a prosperous and sustainable future for the north. Kingston, ACT: Department of Industry, Innovation, Science, Research and Tertiary Education.

Franklin, D. C. (1999). Evidence of disarray amongst granivorous bird assemblages in the savannas of northern Australia, a region of sparse human settlement. Biological Conservation, 90, 53-68. doi.org/10.1016/S0006-3207 (99)00010-5

Hilbert, D. W., Hill, R., Moran, C., Turton, S. M., Bohnet, I., Marshall, N. A., ... Westcott, D. A. (2014). Climate change issues and impacts in the Wet Tropics NRM Cluster Region. Retrieved from publications.csiro.au/rpr/download? pid=csiro:EP14913\&dsid=DS3

Hill, R., Maclean, K., Pert, P. L., Rist, P., Joyce, A., Schmider, J. \& Tawake, L. (2013, December). Project 12.1 Technical Report: Participatory evaluation of co-management in wet tropics country. Interim report-December 2013. Cairns, Qld: Reef and Rainforest Research Centre Ltd. Retrieved from www. nerptropical.edu.au/publication/project-121-technical-report-participatoryevaluation-co-management-wet-tropics-country

James Cook University (JCU) \& Commonwealth Scientific and Industrial Research Organisation (CSIRO). (2013). Land tenure in northern Australia: Opportunities and challenges for investment. Brisbane, Qld: CSIRO.

Landcare Council of the Northern Territory (LCNT). (2005). Integrated natural resource management plan for the Northern Territory: Sustaining our resourcespeople, country and enterprises. Darwin, NT: Department of Infrastructure, Planning and Environment.

Martell, C., Carson, D. \& Taylor, A. (2013). Changing patterns of migration to Australia's Northern Territory: Evidence of new forms of escalator migration to frontier regions? Migration Letters, 10(1), 91-100.

National Natural Resource Management Policy Statement Steering Committee. (1999). Managing natural resources in rural Australia for a sustainable future: A discussion paper for developing a national policy. Canberra, ACT: Department of Agriculture, Fisheries and Forestry (Australia). 
Paton, S., Curtis, A., McDonald, G. \& Woods, M. (2004). Regional natural resource management: Is it sustainable. Australasian Journal of Environmental Management, 11(4), 259-267. doi.org/10.1080/14486563.2004.10648622

Rangelands NRM Coordinating Group. (2005). Rangelands NRM strategy \& investment plan. Perth, WA: Rangelands NRM Coordinating Group.

Russell-Smith, J., Yates, C., Edwards, A., Allan, G. E., Cook, G. D., Cooke, P., ... Smith, R. (2003). Contemporary fire regimes of northern Australia, 1997-2001: Change since Aboriginal occupancy, challenges for sustainable management. International Journal of Wildland Fire, 12(4), 283-297. doi.org/ 10.1071/WF03015

Ryan, S., Broderick, K., Sneddon, Y. \& Andrews, K. (2010). Australia's NRM governance system: Foundations and principles for meeting future challenges. Canberra, ACT: Australian Regional NRM Chairs. Retrieved from nrm regionsaustralia.com.au/wp-content/uploads/2013/12/NRM-Governancein-Australia.pdf

Stephens, A., Oppermann, E., Turnour, J., Brewer, T., O’Brien, C., Rayner, T., ... Dale, A. P. (2015). Identifying tensions in the development of northern Australia: Implications for governance. Journal of Economic and Social Policy, $17(1)$.

Territory NRM. (2010). Northern Territory integrated natural resource management plan 2010-2015. Darwin, NT: Territory Natural Resource Management.

Territory NRM. (2014). Annual Report 2013-14. Darwin, NT: Territory NRM.

Van Oosterzee, P., Dale, A. \& Preece, N. D. (2013). Integrating agriculture and climate change mitigation at landscape scale: Implications from an Australian case study. Global Environmental Change, 29, 306-317. doi.org/10.1016/ j.gloenvcha.2013.10.003

Wentworth Group. (2008). Accounting for nature. A model for building the national environmental accounts of Australia. Sydney, NSW: Wentworth Group of Concerned Scientists. Retrieved from wentworthgroup.org/2008/05/ accounting-for-nature-a-model-for-building-the-national-environmentalaccounts-of-australia/2008/

Whitehead, P., Purdon, P., Cooke, P., Russell-Smith, J. \& Sutton, S. (2009). The West Arnhem Land Fire Abatement (WALFA) project. In J. RussellSmith, P. J. Whitehead \& P. Cooke (Eds), Culture, ecology, and economy of fire management in North Australian Savannas: Rekindling the Wurrk tradition (pp. 287-312). Collingwood, Vic.: CSIRO. 
Williams, J., Read, C., Norton, T., Dovers, S., Burgman, M., Proctor, W. \& Anderson, H. (2001). Biodiversity theme report. In Australian State of the Environment Committee (Ed.), Australia state of the environment report 2001 (pp. 69-82). Canberra, ACT: CSIRO Publishing on behalf of the Department of the Environment and Heritage. Retrieved from soe.environment.gov.au/ sites/g/files/net806/f/soe2001.pdf?v=1487243878

Woinarski, J., Mackey, B., Nix, H. \& Traill, B. (2007). The nature of northern Australia: Its natural values, ecological processes and future prospects. Canberra, ACT: ANU Press. doi.org/10.22459/NNA.07.2007.

Woinarski, J. C. Z., Burbidge, A. A. \& Harrison, P. L. (2015). Ongoing unraveling of a continental fauna: Decline and extinction of Australian mammals since European settlement. Proceedings of the National Academy of Sciences of the United States of America, 112(15), 4531-4540. doi.org/10.1073/pnas.1417301112

Woinarski, J. C. Z., Pavey, C., Kerrigan, R., Cowie, I. \& Ward, S. (Eds). (2007). Lost from our landscape: Threatened species of the Northern Territory. Palmerston, NT: Department of Natural Resources, Environment and the Arts.

Woinarski, J. C. Z., Traill, B. N. \& Booth, C. (2014, 14 October). The modern outback: Nature, people and the future of remote Australia. The Pew Charitable Trusts. Retrieved from www.pewtrusts.org/en/research-and-analysis/reports/ 2014/10/the-modern-outback 
This text is taken from Leading from the North: Rethinking Northern Australia Development, edited by Ruth Wallace, Sharon Harwood, Rolf Gerritsen, Bruce Prideaux, Tom Brewer, Linda Rosenman and Allan Dale, published 2021 by ANU Press, The Australian National University, Canberra, Australia. 